\section{Færre provoserte aborter}

Tallene for provosert abort går ned i mellominntekts- og høyinntektsland, men er uendret i lavinntektsland. Det er kvinner i ekteskap eller samboerskap som får utført flest aborter.

Forekomsten av provosert abort i 184 land over hele verden for perioden 1990-2014 er nylig undersøkt gjennom en systematisk analyse av studier og statistikk (1).

På verdensbasis var det 35 provoserte aborter per 1000 kvinner $i$ alderen 15-44 år. Dette utgjør en svak, men ikke-signifikant nedgang sammenliknet med perioden 1990-94. I mellominntekts- og høyinntektsland gikk abortratene betydelig ned, fra 46 aborter per 1000 kvinner i perioden 1990-94 til 27 per 1000 i 2010-14. I lavinntektsland var det derimot ingen signifikant nedgang.

Karibiske land hadde den høyeste raten for provosert abort, med 65 per 1000 kvinner per år, mens Nord-Amerika og VestEuropa hadde den laveste, med 17 og 18 aborter per 1000 kvinner per år. ØstEuropa hadde den største reduksjonen $i$ abortrater - mer enn en halvering.

På globalt nivå ble det beregnet at hver fjerde graviditet endte med provosert abort i 2010-14. Det ble ikke funnet noen forskjell av betydning i abortratene mellom land der provosert abort er forbudt og land hvor det er selvbestemt abort. I perioden 2010-14 ble $73 \%$ av provoserte aborter utført hos kvinner som levde i ekteskap eller ekteskapslignende forhold.

Forskerne bak rapporten mener at bedre tilgang på og kunnskap om prevensjon og familieplanlegging, spesielt i lavinntektsland, vil kunne forebygge millioner av uønskede svangerskap.

\section{Matilde Risopatron Berg}

Holter legekontor, Nannestad

\section{Litteratur}

1. Sedgh G, Bearak J, Singh S et al. Abortion incidence between 1990 and 2014: global, regional, and subregional levels and trends. Lancet 2016 ; 388: $258-67$.

\title{
Vaksineskepsis i Kina
}

\author{
Befolkningens tillit til hepatitt B-vaksinen falt etter medieoppslag om \\ dødsfall hos vaksinerte spedbarn. Det er ingen holdepunkter for at døds- \\ fallene skyldtes vaksinen.
}

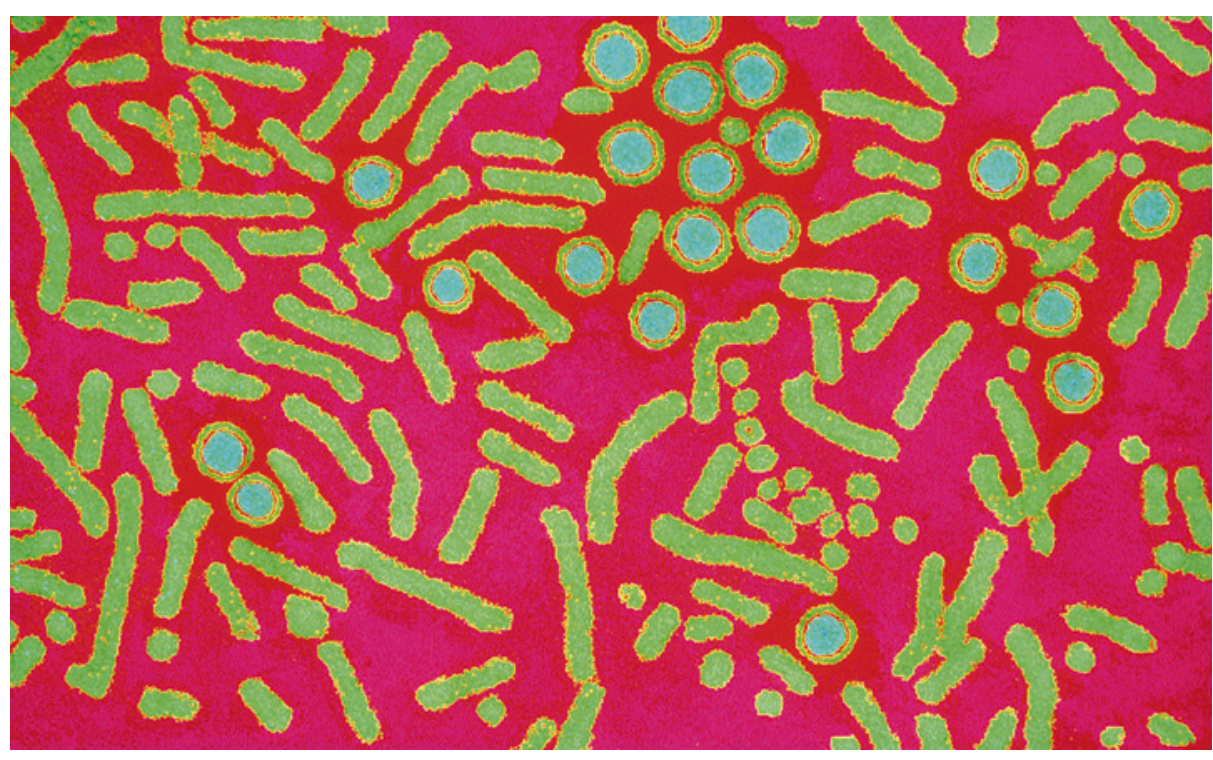

Farget elektronisk mikrofotografi (coloured transmission electron micrograph, TEM) av hepatitt B-viruset og dets antigen. De blå rundingene (Dane-partikler) inneholder hele viruset. Foto: Science Photo Library

I Kina blir det født mer enn 750000 barn årlig av hepatitt B-bærende mødre. Av nyfødte som blir smittet med hepatitt B, vil rundt $90 \%$ utvikle kronisk infeksjon, med høy risiko for senere levercirrhose og -kreft. Siden 1992 er nyfødte i Kina blitt vaksinert mot hepatitt B. Vaksinen gis innen 24 timer etter fødselen og ved én og seks måneders alder. Forekomsten av kronisk hepatitt $\mathrm{B}$ hos barn under fem år sank fra rundt 9,8\% i 1992 til 1,0\% i 2006.

Medio desember 2014 rapporterte kinesiske medier om dødsfall hos 17 nyfødte i etterkant av hepatitt B-vaksinering. En omfattende granskning viste at ett av barna døde av anafylaktisk reaksjon, mens dødsårsaken hos de øvrige ikke var relatert til vaksinen.

Forskere fra kinesiske helsemyndigheter har telefonintervjuet foreldre om deres tiltro til hepatitt B-vaksinens sikkerhet (1). Måneden før medieoppslagene rapporterte $85 \%$ at de oppfattet vaksinen som sikker, mens andelen falt til $27 \%$ mens granskingen pågikk. Åtte måneder senere anså $68 \%$ av dem som kjente til medieoppslagene vaksinen som trygg.
Antall administrerte vaksiner sank med 19\% mens saken ble gransket, men var tilbake på tidligere nivå etter to måneder. Beregninger viser at hundrevis av spedbarn er uvaksinert som følge av den forbigående svikten i vaksinering.

Grunnen til at hepatitt B-vaksinene ble assosiert med spedbarnsdød forklares med at dette er den eneste vaksinen som gis i to doser første levemåned. Fordi dødeligheten første leveår i Kina er på 1,2\%, med flest dødsfall den første måneden, vil mange dødsfall tilfeldig skje kort tid etter vaksinering, uten at det er noen kausal sammenheng.

\section{Kristoffer Brodwall}

Institutt for global helse og samfunnsmedisin Universitetet i Bergen

\section{Litteratur}

1. Yu W, Liu D, Zheng J et al. Loss of confidence in vaccines following media reports of infant deaths after hepatitis $B$ vaccination in China. Int J Epidemiol 2016; 45: 441-9. 